\title{
CROP COEFFICIENT REGIONALIZATION FOR IRRIGATED AGRICULTURE PLANNING IN MARANHÃO STATE -BRAZIL
}

Doi:http://dx.doi.org/10.1590/1809-4430-Eng.Agric.v37n5p953-960/2017

\section{WILSON A. DA SILVA ${ }^{1 *}$, JHONATA S. SANTANA ${ }^{2}$, CRISTIANE M. DA SILVA ${ }^{3}$, ACASSIO A. NUNES ${ }^{2}$}

${ }^{1 *}$ Corresponding author. Universidade Estadual da Região Tocantina do Maranhão - UEMASUL/ Imperatriz - MA, Brasil. E-mail: wilsonuemasul@gmail.com

\begin{abstract}
Irrigated agriculture has emerged as a necessary technology to achieve greater productivity, mainly by supplying the water requirements of agricultural crops in critical periods, especially for those regions where natural rainfall is insufficient to meet these requirements. The daily water consumption of crops is strongly influenced by local weather conditions, which justifies the need for regionalized studies of the parameters influencing the water depth to be applied. The crop coefficient $(\mathrm{Kc})$ is perhaps the most important parameter because it interferes directly with the crop water requirements. This index must be determined for each region, thus avoiding the use of reference values meant for other climatic conditions, causing loss of productivity The present study aimed to estimate the local crop coefficients for corn (Zea mays L.) for the climatic conditions of the State of Maranhão, aiming at the rational use of water in agriculture. The method, which allowed obtaining the local values of $\mathrm{Kc}$ for different phases of the crop cycle, used climatic data from 12 weather stations (INMET) and mathematical equations proposed by Albuquerque et al. (2001). It estimated the mean and final Kc values. The local values of Kc obtained for corn ranged from 0.73 to $0.77,1.00$ to 1.31 , and 0.24 to 0.45 for initial, intermediate, and final phases, respectively.
\end{abstract}

KEYWORDS: water requirements, irrigation, Zea mays L.

\section{INTRODUCTION}

Among the approaches for the estimation of water consumption by plants, crop coefficients $(\mathrm{Kc})$ associated with reference evapotranspiration $\left(\mathrm{ET}_{0}\right)$ estimates stand out. A crop coefficient $(\mathrm{Kc})$ is a widely used parameter in the estimation of water consumption by plants. Therefore, it is of fundamental importance to determine this coefficient for the local conditions in which it will be used since the water flow dynamics is a joint function of local climatic factors (Lopes et al., 2011). Local Kc values are important measures to determine crop water requirements and for a rational irrigation management. This coefficient also aims to maintain the amount of water within the capacity level for absorption and utilization by plant root system (Silva et al., 2013).

Crop development stage, cultivar, and local climate and soil conditions result in different $\mathrm{Kc}$ values compared to the reference one, available in the literature. Hence, these local parameters are of fundamental importance (Souza et al., 2011). Andrade et al. (2013) defined the term crop coefficient $(\mathrm{Kc})$ as the ratio between maximum crop evapotranspiration $\left(\mathrm{ET}_{\mathrm{M}}\right)$ and the reference evapotranspiration $\left(\mathrm{ET}_{0}\right)$. The crop coefficient $\mathrm{Kc}$ varies with plant development, beginning with small values during establishment $\left(\mathrm{Kc}_{\mathrm{i}}\right)$, reaching a maximum value in full developed plants $\left(\mathrm{Kc}_{\mathrm{m}}\right)$ and, then, decreasing at the end of vegetative cycle and early maturation $\left(\mathrm{Kc}_{\mathrm{f}}\right)$, according to Allen et al. (1998) cited by Souza et al. (2012)

The values of $\mathrm{Kc}$ for various crops, development phase, and climatic conditions are presented in FAO-56, according to Allen et al. (1998). However, since the climatic and agronomic conditions of most crops are distinct from those in which reference values were obtained, local estimation is mandatory, avoiding underestimating or overestimating the water depths applied to crops in each

\footnotetext{
${ }^{2}$ Universidade Estadual do Maranhão -UEMA - CESI/ Imperatriz - MA, Brasil.

${ }^{3}$ Universidade Estadual da Região Tocantina do Maranhão - UEMASUL/ Imperatriz - MA, Brasil. 
region. This need is also corroborated by studies developed for other crops in other regions (Lyra et al., 2012; Andrade et al., 2013). Andrade et al. (2013) estimated crop coefficients for different phases of watermelon development and found mean Kc values for phenological stages higher than the reference values presented by FAO. Likewise, Lyra et al. (2012) registered $\mathrm{Kc}_{\mathrm{i}}$ values, adjusted for sugarcane, 2.5 to $35 \%$ higher than are those proposed by FAO-56 guidelines.

Twelve INMET conventional weather stations are well distributed throughout the state of Maranhão, which allows a good coverage of the studied phenomenon. Given such good spatial arrangement of stations and the use of reliable methods for local estimates of Kc, our research also aims to minimize the scarcity of this type of study in this territory. This state is a pioneer in northeastern Brazil and presents a great agricultural potential, contributing to the scientific knowledge on water rational management in agriculture, near the newest agricultural frontier of the country, known as MATOPIBA.

Considering the importance of Kc local estimation for each agricultural crop and its respective influence on the water depths to be irrigated associated with the lack of local information, the objective of this study was to estimate the values of Kc for corn (Zea mays L.) grown during the dry

season in the State of Maranhão. For all the aforementioned reasons, and considering the good distribution of stations and the use of a reliable method, the spatialization of the Kc values obtained in this study may expand these values beyond the studied points.

\section{MATERIAL AND METHODS}

In this study, we simulated an irrigated corn crop grown in the State of Maranhão, within a surface area of $331,983.29 \mathrm{~km}^{2}$. Concerning territorial extension, Maranhão is the eighth largest state in Brazil, and the second one in the Northeastern area, being located between the geographic coordinates of $1^{\circ} 01^{\prime}$ and $10^{\circ} 21^{\prime}$ South Latitude with $41^{\circ} 48^{\prime}$ and $48^{\circ} 50^{\prime}$ West Longitude. To the north, it is bordered by the Atlantic Ocean, to the south and southwest by the State of Tocantins, to the west by Pará, and to the east and southeast by Piauí state.

In this study, the climatic water balance proposed by Thornthwaite \& Mather (1955) was used, aiming to define the periods to be adopted in planting simulations (critical periods). Planting simulation period was defined between May 1 to September 28, months of higher crop water requirements locally, which correspond to the dry season in most parts of the State. Thus, the present study aimed to determine the regionalized Kc values to improve water depth estimation for corn during the dry season in the State of Maranhão. For water requirements, data from 12 weather stations linked to the INMET (National Institute of Meteorology) network were used.

The stations were selected based on climatic data availability and spatial distribution. A continuous series of 22 years of climatic data (from 1995 to 2016) was adopted regarding minimum relative humidity, wind speed, and mean temperature. Table 1 shows the stations used in the study.

TABLE 1. Code, name, latitude, longitude, and altitude of the used stations.

\begin{tabular}{clccc}
\hline Code & Name & Latitude $(\mathrm{S})$ & Longitude $(\mathrm{W})$ & Altitude $(\mathrm{m})$ \\
\hline 82970 & Alto Parnaíba-MA & $09^{\circ} 07^{\prime}$ & $45^{\circ} 56^{\prime}$ & 285.05 \\
82460 & Bacabal-MA & $04^{\circ} 05^{\prime}$ & $44^{\circ} 45^{\prime}$ & 25.07 \\
82571 & Barra do Corda-MA & $05^{\circ} 30^{\prime}$ & $45^{\circ} 16^{\prime}$ & 153.00 \\
82768 & Balsas-MA & $07^{\circ} 30^{\prime}$ & $46^{\circ} 10^{\prime}$ & 259.37 \\
82765 & Carolina-MA & $07^{\circ} 19^{\prime}$ & $47^{\circ} 28^{\prime}$ & 183.00 \\
82476 & Caxias-MA & $04^{\circ} 51^{\prime}$ & $43^{\circ} 20^{\prime}$ & 103.56 \\
82676 & Colinas-MA & $05^{\circ} 58^{\prime}$ & $44^{\circ} 14^{\prime}$ & 179.75 \\
82382 & Chapadinha-MA & $03^{\circ} 43^{\prime}$ & $43^{\circ} 25^{\prime}$ & 103.50 \\
82564 & Imperatriz-MA & $05^{\circ} 34^{\prime}$ & $47^{\circ} 35^{\prime}$ & 123.30 \\
82280 & São Luis-MA & $02^{\circ} 35^{\prime}$ & $44^{\circ} 14^{\prime}$ & 32.00 \\
82198 & Turiaçu-MA & $01^{\circ} 43^{\prime}$ & $45^{\circ} 24^{\prime}$ & 44.08 \\
82376 & Zé Doca-MA & $03^{\circ} 43^{\prime}$ & $45^{\circ} 19^{\prime}$ & 45.98 \\
\hline
\end{tabular}


For Kc regionalization and subsequent water depth estimations, planting simulations were carried out for corn crop at each selected station, considering data in Table 2, replicating an agricultural scenario with crop cycles and respective cultivation periods.

TABLE 2. Corn crop cycle phases and cultivation periods adopted in the study.

\begin{tabular}{lc}
\hline \multicolumn{1}{c}{ Crop cycle phase } & Period \\
\hline I - Planting - establishment & $05 / 01$ to $06 / 19$ \\
II - Vegetative Growth & $06 / 20$ to $08 / 28$ \\
III - Flowering- grain filling-maturation & $08 / 29$ to $09 / 28$ \\
\hline
\end{tabular}

For local estimation of initial crop coefficients (Kci), we used the proposal by Albuquerque et al. (2001), which was also assumed by other authors in other states such as Carvalho et al. (2006), who applied the same equation in the State of Rio de Janeiro.

The equation proposed by Albuquerque uses $\mathrm{ET}_{0}$ and soil moistening period (IE) in the estimation of local crop coefficients (Kci) (Equation 1).

$$
\mathrm{Kci}=1.42-0.09 . \mathrm{ETo}-0.11 . \mathrm{IE}+0.004 . \mathrm{ETo}^{2}+0.003 . \mathrm{IE}^{2}+0.0003 . \mathrm{ETo} . \mathrm{IE}
$$

where,

Kci - Regionalized initial crop coefficient, non-dimensional;

$\mathrm{ET}_{0}$ - Reference evapotranspiration in phase I, mm.day ${ }^{-1}$,

IE - Interval between soil moistening events (rainfall or irrigation), days.

For intermediate $(\mathrm{Kcm})$ and final $(\mathrm{Kcf})$ coefficients, we used the equations proposed by Pereira \& Allen (1997) (equations 2 and 3), which accounts daily climatic data referring to minimum humidity and mean wind speed, besides crop data as plant canopy mean height, and tabulated data according to Doorenbos \& Pruitt (1977), as described in the equations below:

$$
\begin{aligned}
& \mathrm{Kcm}=\mathrm{kcm}(\text { Padrão })+\left[0.04\left(U_{2}-2\right)-0.004\left(U R_{\text {min }}-45\right)\right] .\left(h_{1} / 3\right)^{0.3} \\
& \mathrm{Kcf}=\operatorname{kcf}(\text { Padrão })+\left[0.04\left(U_{2}-2\right)-0.004\left(U R_{\min }-45\right)\right] .\left(h_{1} / 3\right)^{0.3}
\end{aligned}
$$

where,

Kcm - Regionalized mean crop coefficient, Non-dimensional;

Kcf - Regionalized final crop coefficient, Non-dimensional;

Kcm (Standard) - Mean crop coefficient recommended according to Doorenbos \& Pruitt (1977), Non-dimensional;

Kcf (standard) - Final crop coefficient recommended according to Doorenbos \& Pruitt (1977), Non-dimensional;

$\mathrm{ET}_{0}$ - Reference evapotranspiration in phase I, mm.day ${ }^{-1}$;

IE - Interval between soil moistening events (rainfall or irrigation), days;

$\mathrm{U} 2$ - Wind speed at $2 \mathrm{~m}$ high, $\mathrm{m} . \mathrm{s}^{-1}$;

$\mathrm{RH}_{\min }$ - Minimum relative humidity;

h1 - Mean height of the crop in phase II, $\mathrm{m}$, and

h2 - Mean height of the crop in phase III, $\mathrm{m}$. 
$\mathrm{ET}_{0}$ values in equation 1 were estimated by FAO Penman-Monteith method, according to Allen (1998). The parameters (U2 and $\mathrm{RH}_{\min }$ ) were obtained taking into account the number of days corresponding to each crop cycle phase (Table 2).

The Kcm (standard) and Kcf (standard) adopted were 1.20 and 0.35 , respectively, as stated by Doorenbos \& Pruitt (1977). The plants in phases II and III were 2-m high and the interval between moistening events was four days. Tables displaying the estimated Kc values for each station were generated, showing the values corrected for each location for further comparison with FAO 56 recommendations.

\section{RESULTS AND DISCUSSION}

In the studied towns, the estimated Kc for corn ranged from 0.73 to $0.77,1.00$ to 1.31 , and 0.24 to 0.45 for initial, intermediate, and final phases, respectively. These ranges were different from those suggested by FAO. The findings for Maranhão state had the same trend of those found by Carvalho et al. (2006) for the state of Rio de Janeiro.

For most of the months, the regionalized Kc values were higher than the ones recommended by FAO $(0.5,1.2$, and 0.35$)$, as shown in Table 3.

TABLE 3. Kc values recommended by FAO and regionalized for different towns and months.

\begin{tabular}{|c|c|c|c|c|c|c|c|}
\hline \multirow{3}{*}{ Town } & \multirow{3}{*}{ Month } & \multicolumn{3}{|c|}{$\mathrm{Kc}(\mathrm{FAO})$} & \multicolumn{3}{|c|}{ Kc (Reg.) } \\
\hline & & \multicolumn{3}{|c|}{ Crop Cycle } & \multicolumn{3}{|c|}{ Crop Cycle } \\
\hline & & Phase I & Phase II & Phase III & Phase I & Phase II & Phase III \\
\hline \multirow{7}{*}{ ALTO PARNAÍBA } & May & 0.5 & & & 0.74 & & \\
\hline & June & 0.5 & & & 0.73 & & \\
\hline & July & & 1.2 & & & 1.25 & \\
\hline & Aug & & 1.2 & & & 1.28 & \\
\hline & Set & & & 0.35 & & & 0.43 \\
\hline & May & 0.5 & & & 0.75 & & \\
\hline & June & 0.5 & & & 0.75 & & \\
\hline \multirow{5}{*}{ BACABAL } & July & & 1.2 & & & 1.19 & \\
\hline & Aug & & 1.2 & & & 1.22 & \\
\hline & Set & & & 0.35 & & & 0.42 \\
\hline & May & 0.5 & & & 0.74 & & \\
\hline & June & 0.5 & & & 0.74 & & \\
\hline \multirow{2}{*}{ BALSAS } & July & & 1.2 & & & 1.26 & \\
\hline & Aug & & 1.2 & & & 1.28 & \\
\hline \multirow{7}{*}{ CAROLINA } & Set & & & 0.35 & & & 0.43 \\
\hline & May & 0.5 & & & 0.75 & & \\
\hline & June & 0.5 & & & 0.74 & & \\
\hline & July & & 1.2 & & & 1.27 & \\
\hline & Aug & & 1.2 & & & 1.31 & \\
\hline & Set & & & 0.35 & & & 0.45 \\
\hline & May & 0.5 & & & 0.74 & & \\
\hline \multirow{4}{*}{ CAXIAS } & June & 0.5 & & & 0.74 & & \\
\hline & July & & 1.2 & & & 1.23 & \\
\hline & Aug & & 1.2 & & & 1.25 & \\
\hline & Set & & & 0.35 & & & 0.43 \\
\hline
\end{tabular}




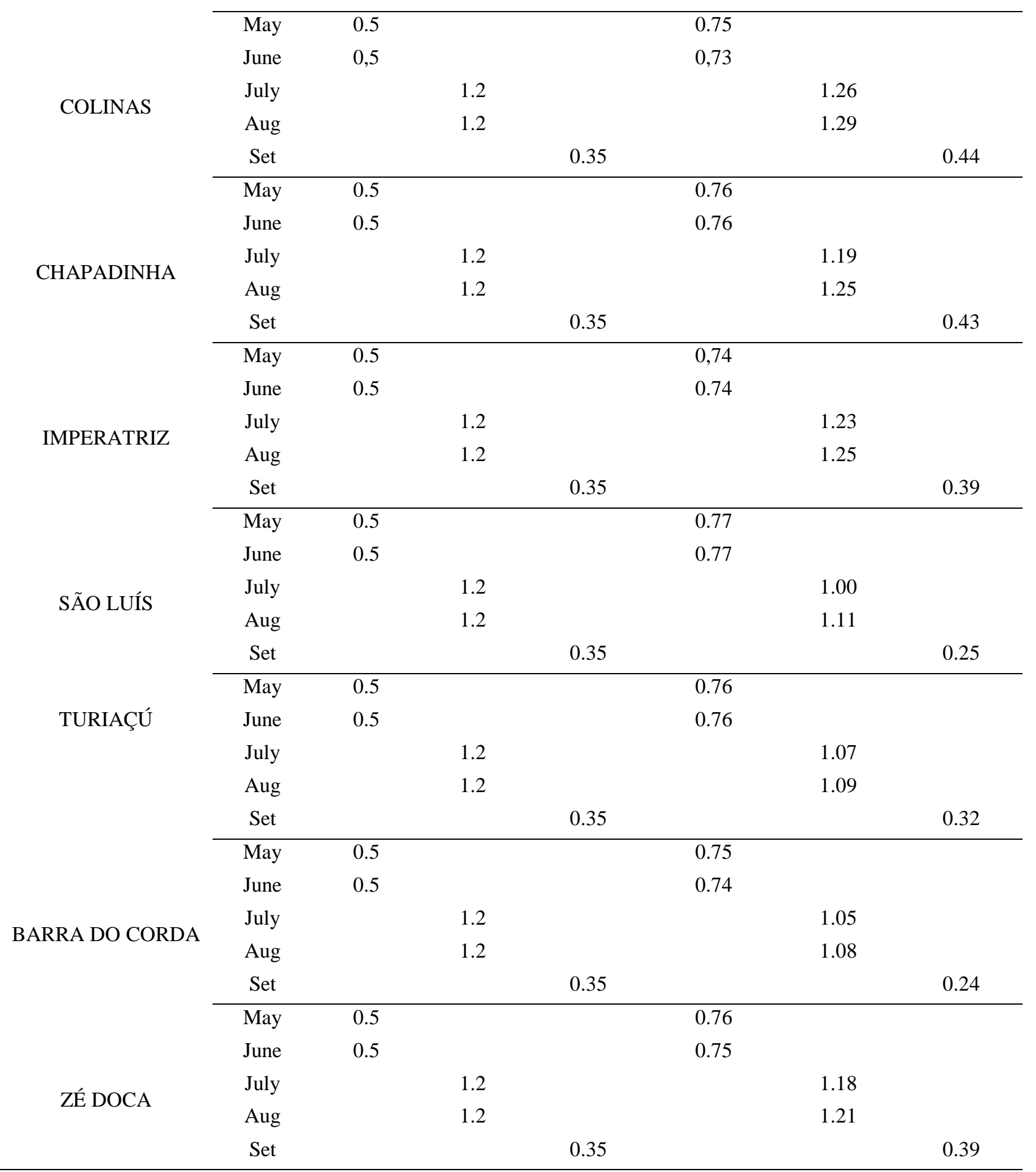

Table 3 clearly shows that the values of Kc suggested by FAO (Kc FAO) are smaller than the regionalized values found for all the studied towns (Kc Reg.) during phase I of corn cycle. Such difference may lead to underestimations of the water depth to be irrigated, causing water stress at the beginning of development and, consequently, lower productivities.

Likewise, the same results were found for phase II for the towns of São Luís, Turiaçu, and Barra do Corda. Yet the towns of Bacabal, Chapadinha, and Zé Doca had lower values only in July, which could favor leaching of nutrients and unnecessary expenses with electricity and labor.

Again, the values of $\mathrm{Kc}$ recommended by FAO are smaller than were those estimated for phase II, on a regional scale for the towns of Carolina, Caxias, Colinas, Alto Parnaíba, Balsas, and Imperatriz. It also may contribute to water deficit in phase II and result in loss of productivity. 
For phase III, which corresponds to the flowering and grain filling until maturation, local Kc values were higher than the values proposed by FAO for the towns of Alto Parnaíba, Balsas, Carolina, Caxias, Colinas, Chapadinha, Imperatriz, and Zé Doca. While for the towns of São Luis, Turiaçú, and Barra do Corda, they were lower during the same phase.

In the state of Espírito Santo, Busato \& Busato (2011) observed values of $\mathrm{Kc}_{\mathrm{i}} \mathrm{Kc}_{\mathrm{m}} \mathrm{Kc}_{\mathrm{f}}$ for vines being respectively higher (33\%), lower, and similar to those tabulated by FAO 56 guidelines. Once more, these results highlight the need of correcting Kc values according to local conditions prior to irrigation, especially for crop initial phase. Studying ET and Kc for Cunhã forage, Oliveira et al. (2013) observed a decrease in $26 \%$ of a Kc determined by Class A pan when compared to the standard method of Penman-Monteith (FAO). These authors also pointed out the importance of conducting in situ studies to calibrate crop coefficients.

Silva et al. (2014) proved FAO Kc for sugarcane to be inappropriate for tropical regions, being required an adjustment for its suitability. By contrast, Rios et al. (2011) estimated Kc values of castor beans for growth, vegetative growth, fruiting, and maturation phases within FAO-56 limits and recommendations.

Fancelli \& Dourado Neto (2000) recommended $\mathrm{Kc}_{\mathrm{i}}$ values for corn in Brazil ranging from 0.20 to 0.40 , which are well below the $\mathrm{Kc}_{\mathrm{i}}$ values found here. In this way, if this range of values was adopted for the climatic conditions of Maranhão state, corn crops would certainly undergo water stress at the beginning of development, showing negative effects on final yield.

The Kc values found here can be considered representative since they were based on the standard method of Penman-Monteith. Both FAO (Food and Agriculture Organization of the United Nations) and ICID (International Commission on Irrigation and Drainage) adopted this standard method (FAO-56) for $\mathrm{ET}_{0}$ estimation. This method was chosen as standard given its technical formulation and excellent results under most of the climatic conditions (Bernardo et al., 2005). Globally, the Penman-Monteith-FAO method (PM-FAO) is considered the most suitable for ET $_{0}$ estimates because, besides representing the biophysical phenomenon of evapotranspiration consistently, it is also fed by almost all the meteorological elements observed in surface-based weather stations Carvalho et al. (2011).

\section{CONCLUSIONS}

Based on the analysis of the results presented in this paper, we could establish the following conclusions:

- The Kc values regionally estimated in this study were different from those recommended by FAO for each studied town and corn cycle phase;

- Corn Kc values estimated for Maranhão state ranged from 0.73 to $0.77 ; 1.00$ to 1.31 ; and 0.24 to 0.45 , for initial, intermediate, and final phases, respectively;

- The results found in this research corroborate other studies regarding the need for local studies on different parameters used for estimating the water consumption of agricultural crops.

\section{ACKNOWLEDGMENTS}

The authors would like to thank the State University of Tocantina Region in Maranhão UEMASUL, for the entire physical structure and for providing skilled human capital.

\section{REFERENCES}

Albuquerque PEP, Andrade Junior AS, Sousa F, Sediyama GC, Bezerra JRC, Stone LF, Silveira PM (2001) Coeficientes de cultivo das principais culturas anuais. Revista ITEM - Irrigação e Tecnologia Moderna (52-53):49-57.

Allen RG, Pereira LS, Raes D, Smith M (1998) Crop evapotranspiration: Guidelines for computing crop water requirements. Rome, FAO. 300p. (FAO-irrigation and drainage paper, 56). 
Andrade ARS, Cruz AFS, Cavalcante ECS, Albuquerque JCF, Souza WM (2013) Estimativa da evapotranspiração e dos coeficientes de cultura para diferentes fases de desenvolvimento da melancia. Revista Brasileira de Geografia Física 6(5):1417-1429. Available:

http://www.revista.ufpe.br/rbgfe/index.php/revista/article/viewArticle/770. Accessed: May 11, 2016.

Bernardo S, Soares AA, Montovani EC (2005) Manual de irrigação. Viçosa, MG, UFLA, 8ed. $625 p$.

Busato CCM, Busato C (2011) Evapotranspiração da videira em santa teresa, ES: coeficiente de cultura "único" padrão boletim FAO 56. Revista Verde 6(4):251-257. Available: http://www.gvaa.com.br/revista/index.php/RVADS/article/view/682. Accessed: Jun 7, 2016.

Carvalho LG, Rios GFA, Miranda WL, Neto PC (2011) Evapotranspiração de referência: uma abordagem atual de diferentes métodos de estimativa. Pesquisa Agropecuária Tropical 41(3):456465.

Carvalho DF, Cruz ES, Silva WA, Souza WJ, Alves Sobrinho T (2006) Demanda hídrica do milho de cultivo de inverno no Estado do Rio de Janeiro. Revista Brasileira de Engenharia Agrícola e Ambiental 10(1):112-118. Available: http://www.scielo.br/pdf/rbeaa/v10n1/v10n1a17.pdf. Accessed: Apr 7, 2016. DOI: http://dx.doi.org/10.1590/S1415-43662006000100017

Doorenbos J, Pruitt WO (1977) Guidelines for predicting crop water requirements. Rome, FAO, 144p. (Irrigation and Drainage Paper, 24).

Fancelli AL, Dourado Neto D (2000) Produção de milho. Guaíba, Agropecuária, 360p.

Lopes OD, Kobayashi MK, Oliveira FG, Alvarenga ICA, Martins ER, Corsato CE (2011) Determinação do coeficiente de cultura $(\mathrm{Kc})$ e eficiência do uso de água do alecrim-pimenta irrigado. Revista Brasileira de Engenharia Agrícola e Ambiental 15(6):548-553. Available: http://www.scielo.br/scielo.php?script=sci_arttext\&pid=S1415-43662011000600002. Accessed: Apr 7, 2016. DOI: 10.1590/S1415-43662011000600002

Lyra GB, Silveira EL, Lyra GB, Pereira CR, Silva LDB, Silva GM (2012) Coeficiente da cultura da cana-de-açúcar no estádio inicial de desenvolvimento em campos dos Goytacazes, RJ. Irriga 17(1):102-113. Available: http://revistas.fca.unesp.br/index.php/irriga/article/view/390. Accessed: Apr 7, 2016. DOI: http://dx.doi.org/10.15809/irriga.2012v17n1p102

Oliveira GM, Miranda M, Leitão VBR, Santos IMS, Bispo RC, Mistura C (2013)

Evapotranspiração e coeficiente de cultura da forrageira cunhã (Clitoriaternatea L.) para diferentes fases fenológicas e épocas do ano. Revista Verde 8(2):203-209. Available: http://www.gvaa.com.br/revista/index.php/RVADS/article/view/1853. Accessed: Apr 7, 2016.

Pereira LS, Allen RG (1997) Novas aproximações aos coeficientes culturais. Engenharia Agrícola 3(4):118-143.

Silva VPR, Borges CJR, Albuquerque WG (2014) Necessidades hídricas da cana-de-açúcar cultivada em clima tropical. Semina 35(2):625-632. Available: http://www.uel.br/revistas/uel/index.php/semagrarias/article/view/12734 . Accessed: Apr 7, 2016.

Silva VPR, Tavares AL, Sousa IF (2013) Evapotranspiração e coeficientes de cultivo simples e dual do coentro. Horticultura Brasileira 31(2):255-259. Available: http://www.scielo.br/pdf/hb/v31n2/13.pdf. Accessed: Apr 7, 2016.

Souza AP, Carvalho DF, Silva LBD, Almeida FT, Rocha HS (2011) Estimativas da evapotranspiração de referência em diferentes condições de nebulosidade. Pesquisa Agropecuária 46(3):219-228. Available: http://www.scielo.br/pdf/pab/v46n3/a01v46n3.pdf. Accessed: Apr 7, 2016. 
Souza AP, Lima ME, Carvalho DF (2012) Evapotranspiração e coeficientes de cultura do milho em monocultivo e em consórcio com a mucuna-cinza, usando lisímetros de pesagem. Revista Brasileira de Ciências Agrárias 7(1):142-149. Available:

http://www.agraria.pro.br/sistema/index.php?journal=agraria\&page=article \&op=view \&path $\% 5 B \%$ 5D=agraria_v7i1a802\&path\%5B\%5D=1083. Accessed: Apr 7, 2016.

Rios GFA, Carvalho LG, Magina FC, Castro Neto PC, Silva BM, Fraga AC (2011) Consumo hídrico e coeficiente de cultura da mamoneira na microrregião de Lavras, Minas Gerais. Revista Brasileira de Engenharia Agrícola e Ambiental 15(12):1275-1282. Available: http://www.scielo.br/pdf/rbeaa/v15n12/a09v15n12.pdf. Accessed: Apr 7, 2016. DOI: 10.1590/S1415-43662011001200009

Thornthwaite CW, Mather JR (1955) The water balance. Centerton, NJ: Drexel Institute of Technology, Laboratory of Climatology, 104p. 